\title{
The suckling pig chronicles Kolonga day in Auckland
}

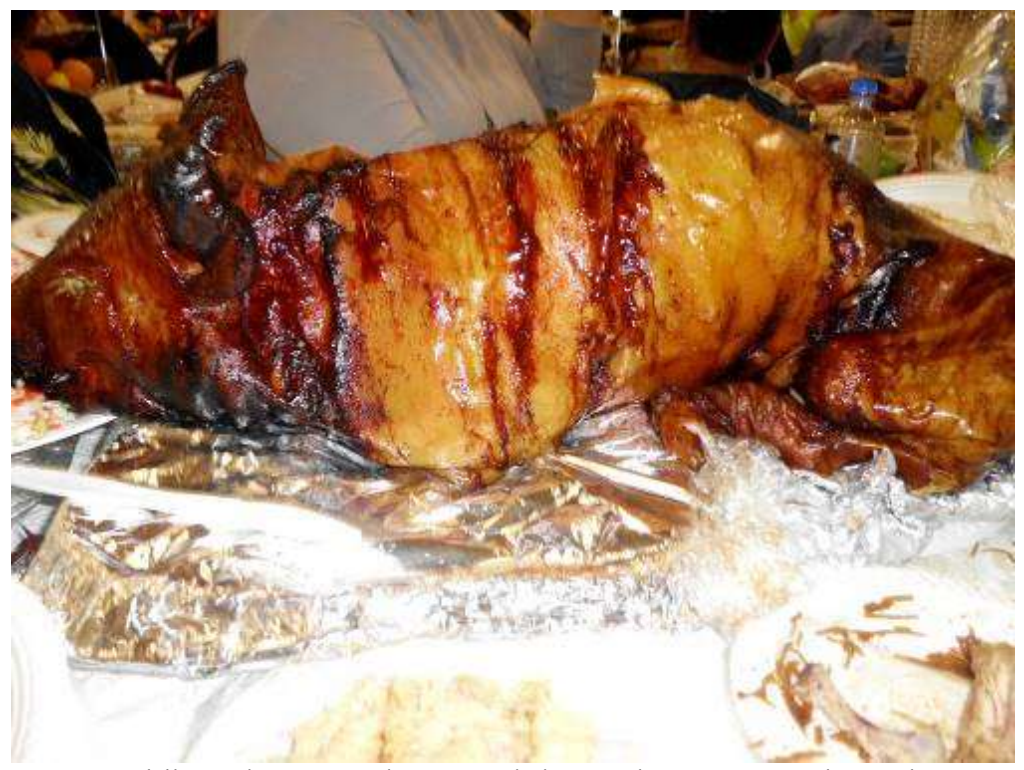

A suckling pig roasted on a spit is ready to eat on the Pulu kinfolk table at Kolonga day in Auckland. Photograph Credit: Teena Brown.

\section{Abstract}

The Tongan diaspora of New Zealand, Australia, and the United States has invented the observance of village days. Auckland affiliates to Kolonga, a rural farming settlement in

Teena Brown is an anthropologist and Senior Lecturer in Pacific Development in the Faculty of Maori and Indigenous Development at Auckland University of Technology.

Richard Pamatatau is a journalist and programme leader of the graduate diploma in Pacific journalism in the School of Communication Studies at Auckland University of Technology. 
Tonga, held an inaugural village day on October 26th, 2015. The result generated mixed feelings. The greater part wanted Kolonga day made a regular celebration. Others thought the event could be improved. While some saw the maiden Kolonga day as chaos, which should be reworked to resemble a function less costly and showy, and more down-to-earth and practical. Why have Tongan village days taken off in diaspora, and will they continue to be bankrolled by generations born overseas?

\section{Warning on cultural chaos}

Some of this essay's groundwork is about making sense of cultural chaos, especially when the culture under the ethnographic microscope is meant to be mine, but does not represent my values, canons, customs, and tastes. This was the predicament I found myself in as an anthropologist teaming up with a journalism academic, Richard Pamatatau.

We set out to unearth the village mentality driving Kolonga day. What we got was a range of responses and reactions from village affiliates, and some outside observers, in hindsight of the event. Truthfully, a certain amount of puzzlement and perplexity takes hold when one of the co-researchers, in this case Teena, feels conflicted probing cultural chaos because first, the culture is assumed to be hers, and second, the cultural performance she finds unsettling.

Cultural chaos in the Kolonga day context refers to Eric Hobsbawm and Terence Ranger's classic text, The Invention of Tradition, as it unravels in diaspora. (Hobsbawm and Ranger, 1983). It interrogates the confusion and unruliness that transpires in performing small island culture outside of the homeland state. What is the end result when The Invention of Tradition does not reflect the original product it is mirrored on, the village in Tonga that is? (Hobsbawm and Ranger, 1983).

This essay is edgy, anxious, and troubling because it speaks to unpopular and popular narratives about inventing culture in diaspora. Poking at an observance that at a glance 
looks doubtful, in terms of practical worth to the village in the homeland state, the problematic is reframed: was Kolonga day the product of disconnection between the diaspora and the Tongan village being celebrated?

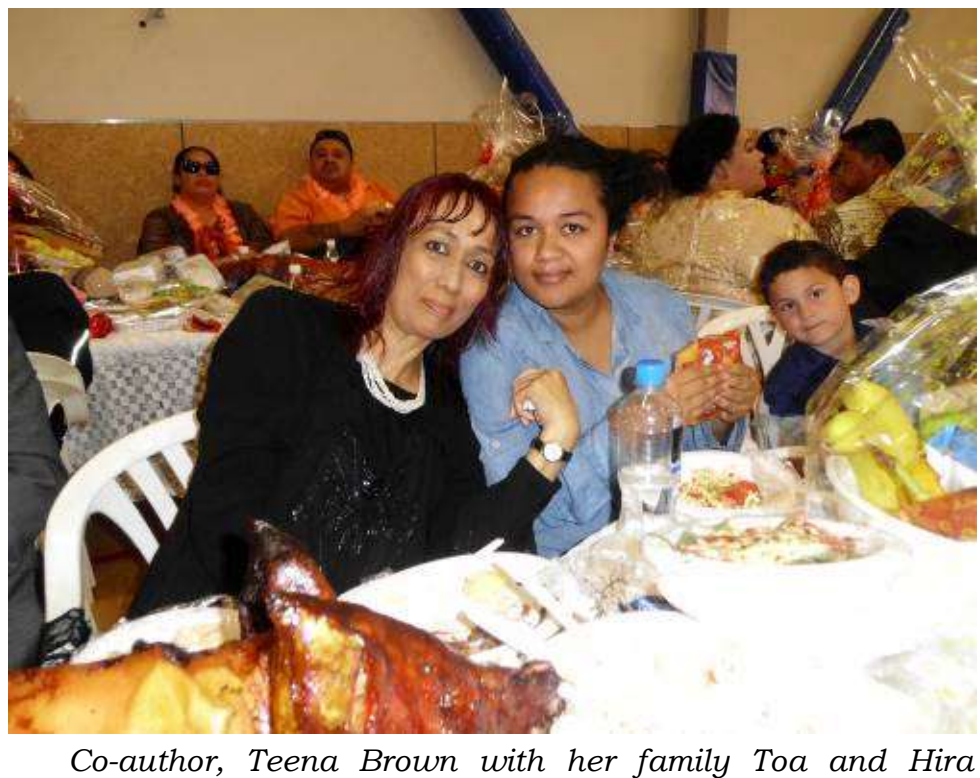
Amoamo at the Pulu kinfolk table for Kolonga day on October 26th, 2015. Photograph Credit: Teena Brown.

\section{Teena's dilemma}

On my New Zealand birth certificate, the first names are Teena Joanne. The surname is Brown Pulu. I have elected to publish as Teena Brown since my mother, Patricia Brown, died in 2015. She named me for her older sister, Tina Brown, who has been deceased since 1989 and is buried at Mala'e 'Aloua in Nuku'alofa with her Tongan mother, 'Ana Kaho.

I am a forty-six year old woman, and a sole-parent. I am an anthropologist employed as a Senior Lecturer at Auckland University of Technology. I am accustomed to independent 
decision making, and being responsible for the consequences of my choices and actions.

It was therefore insufferable being put under pressure by my father, Semi Pulu. He insisted I attend the Kolonga day feast held at the Otahuhu Leisure Centre on October 26th, 2015. (Brown Pulu, 2015a). It was New Zealand Labour Day.

Dad was much pushier than usual because his wife, my mother, Patricia Brown, died three-months ago in Auckland on July 18th. Mum was half-cast European Tongan. Although she was born in Tonga in 1946, she had British citizenship because her father, Stanley Brown, was a British citizen.

For all of my life from childhood to adulthood Mum had been the human shield sheltering me from an invading horde of the father, plus the father's village relatives. Added together, they tallied up to social obligation and financial burden. If Mum was alive she would go hammer-and-tongs at Dad to back off, hollering at him, Kolonga kai mu'a! [Barge in front Kolonga!].

The Kolonga day organising committee had put me in the programme to give a speech, without asking. Kolonga was my Tongan father's village of birth. I was slotted in the middle of Dr Seini Taufa of the University of Auckland, and Jenny Salesa, the Labour Party Member of Parliament for Manukau East, two Tongan women who gave speeches that were the antithesis of mine. (Brown Pulu, 2015b).

Taufa and Salesa were definitely not role-playing the critic and conscience of society. They avoided any critique of power disparity in the way that many poor Kolonga families had been pressured into feeling duty-bound to donate to the occasion beyond their household's financial means.

As Tongan women and guest speakers at this inaugural celebration, how could they go against the establishment? They performed the role expected of them, complying with the day's proceedings by bowing graciously to the village hierarchy of the noble and his family, church ministers, an organising committee, and the people. 
I wanted to boycott the hullaballoo. My estimation of the event was a waste of time, money, and effort. I was knotted and compromised. I felt physically ill on the day, and wanted to go home. I missed my dead mother, who with the help of her older sisters, raised me by half-cast values and behaviours European in composition not Tongan. My gripe was twofold.

A huge ethical dilemma lay in organising an extravagant and pricey feast paid for by poor Kolonga families who could not afford the food expense on humble household budgets. Where did they get the cash to purchase and prepare a lavish spread? The South Auckland loan shark was one answer.

Subsequently, Kolonga village did not benefit from Kolonga day in diaspora. Visibly, there was no practical relationship. The Auckland community had not made Kolonga day a fundraiser for the village at home, who in reality, were struggling to survive worse than they were. What was the point of the celebration? Why name the occasion Kolonga day in the first place? (Brown Pulu, 2015a).

The suckling pig chronicles are co-researched by an anthropologist, Teena Brown, the only child of a migrant Tongan father born in Kolonga, a rural farming village in the eastern district of Tongatapu. Her collaborator is Richard Pamatatau, a journalism academic tracing his ancestry to Mauke in the Cook Islands, and Western Europe.

Teena and Richard weave diverse Kolonga day narratives about tensions and optimisms, likes and loathes, into an ethnographic mosaic of social memory. In the New Zealand diaspora, how do people remember an ancestral village across generations? Why does social memory deviate from historical fact triggering change in Kolonga?

\section{The suckling pig problematic}

It is here the provocative wording chosen for the foreground title, The suckling pig chronicles, requires an explanation. Whole pigs roasted on a spit are the main feature at a Tongan feast. My paternal Pulu clan assented to suckling pigs on 
their two tables covering the hall width. The meat was tenderer. But they could not agree on the number of swine. In his role as the nominated leader for the Pulu kinfolk, my father decided on the amount. However, more pigs appeared on the tables than what had been settled on.

An increasing quantity of suckling pigs symbolises the crowd that jam-packed the hall for Kolonga day. The venue's capacity was under 400 persons at any one time. Glancing around at meal time when the tables were chockfull, it looked as if there could have been a thousand people, or more. This draws attention to the anxiety of staging village day feasts in diaspora.

First of all, by New Zealand standards the overfull hall and amplifier noise level posed a health, safety, and fire risk. Was it the organising committee's responsibility to exert crowd control by pruning back the gathering? Subsequently, how does limiting the number of people allowed at the event stand in direct conflict with the culture argument? That is, the idea it is customary practice for village feasts to have an open-door policy without any constraint on how many people can attend.

A circumstance shaping Pacific Islander occasions in urban settings has to be weighed up in the public regulation versus culture debate. Among the Auckland Kolonga community it was rumoured that many people swarmed the venue specifically for food, and that these Tongans had no connection to the village. They were believed to be families, many of them young people, who had heard through social media and the coconut wireless - a satirical reference to word of mouth - there was feasting going on.

This leads to the youth bulge discussion, and the fact a burgeoning Pacific Islander population under twenty-five years is largely seen as worrisome, and troublesome, for a future New Zealand society. The prevalent rationale is the majority of young Pacific peoples in New Zealand have not gained a highlevel of education, and are confined to the lower end of the job market. How can New Zealand sustain its high standard of 
living and quality of life when Pacific peoples are a growing portion of the workforce constricted to labouring for minimum wage?

This complex dialogue frames the essay's theoretical quandary, accentuating the culture and sustainability question. Conventional logic argues culture adapts and transforms across generations of migrants to their overseasborn descendants to survive changing times. That is an obvious aspect of creating a tradition of Tongan village days in diaspora. But how sustainable is an invented tradition when it is a migrant construct of culture abroad, and the generations born overseas have two options: adopt the practice or reject it.

Tied into the cultural dichotomy of adopt or drop is what Homi K. Bhabha has noted as "third space" peoples. (Bhabha, 1998). These are individuals and groups who occupy a marginal space in society due to their perceived "cultural difference." (Bhabha, 1998). How would an organising committee for Kolonga day police young Tongans from Otahuhu and surrounding neighbourhoods who come for an extravagant meal, and further to that, why should they?

As research collaborators, Richard and I came up with the notion that we were exploring marginality and performativity on two tangled counts. (Butler, 1990; Brown Pulu and Pamatatau, 2015). By this, we mean the Kolonga day feast was a cultural site for people to perform a village identity that was otherwise invisible and marginal to New Zealand society. Here was a gathering of people who did not participate in public culture denoted as Pasifika in New Zealand.

They did not attend museums and art galleries showcasing Pacific collections. They were not the official face of Tongan Language Week. Radio New Zealand did not use them as their go-to people when covering Pacific news and current events.

Tagata Pasifika, Television New Zealand's weekly show of who's who in diverse Pacific communities and Pacific Islands' 
states, was not going to screen a story about them. Who were these nameless, faceless people signifying the village?

Compounding the invisibility and marginality predicament was the fact that Tongan villages and outer-island groups in diaspora did not, as a collective, purchase their own places to hold life-cycle ceremonies. As Richard pointed out, different to Cook Islanders, Tongans did not establish village and outerisland facilities in South Auckland. Instead, they hired Auckland council or church-owned halls to hold their special events.

Edwina and Maurits loved it

"Edwina and Maurits loved it!" texted my co-researcher Richard Pamatatau at eight in the evening. He was talking about his eighty-plus year old mother who was born in Mauke, an island in Nga Pu Toru, a chain in the Southern Cook Islands, and his friend of Dutch ancestry, Maurits.

On New Zealand Labour Day of October 26th, 2015, we attended the inaugural Kolonga Day feast at the Otahuhu Library, Pool, and Leisure Centre on Hall Avenue in South Auckland. Richard and his family had been invited by my father Semi to sit at our table for the Pulu kinfolk. Semi was grateful to Richard for attending my mother's funeral service on July 23rd, and wanted to welcome him, and family members, for a village celebration.

Edwina and Maurits had a different take on the Kolonga Day feast to mine. Sharing their views openly with Richard, he wanted me to know all was not doom and gloom. By piecing together a mosaic of memory about the village event in diaspora, I had to accept popular opinion from not singly Kolonga affiliates, but outside observers, would be upbeat and in favour of continuing the occasion in Auckland. An exploration of conflicting moods - optimism and scepticism as the tone, tenor, and temperament of musings about village day is one prominent theme that has surfaced. 
Thank you again. Edwina and Maurits loved it! They have not stopped talking about how welcome people made them feel. They were moved by that a lot. I've also been told not to be too critical of people trying to carve out a place [from] Edwina, and Maurits says while the room was chaotic that was caused by the room size because the people were operating in their spaces beautifully.

I was held hostage in the field. I mean to say that as an anthropologist, I felt too close to the context-specific ethnography I wanted to unravel for readers, and make sense of on the page. Enter Richard, my colleague at Auckland University of Technology.

As a journalism academic, he shouldered a fair amount of the field research. By working the field, Richard allowed me breathing distance. I was gagging on my own ego and judgements when selecting conversation snippets, and resituating the interchanges in stories characterising, The suckling pig chronicles: Kolonga day in Auckland.

In a motherly tone, Edwina advised Richard not to be overly critical of how the proceedings at Kolonga day had unwrapped. By her reading these were people, who similar to other Pacific Islands' ethnicities and cultures, were trying to fashion a place for themselves in New Zealand.

Creating a space to be acknowledged and valued as part of New Zealand's social tapestry, made me ill at ease. A sizeable crowd of one thousand plus people appeared to be claiming Tongan village affiliation to Kolonga, but, the mass were largely disconnected from the physical village and its inhabitants.

Here were people, almost all with no land entitlement in Kolonga, no homes to upkeep, and no uta or bush allotment to pay rates on. Here were migrants, most not going back to the village permanently, and who hardly ever visited. Here were their New Zealand-born descendants, children and 
grandchildren, the majority never seeing Kolonga in their lives, or only having travelled there once for a holiday.

Edwina spoke further, outlining the contours of privilege. Reminding Richard, "You and Teena didn't grow up surrounded by a village," she sketched the reality of our coresearcher predicament. We traced ancestral descent to our respective villages in the Pacific Islands' countries of the Cook Islands and Tonga. However, not being born and raised there meant we were not socialised by village life.

Not brought up under the proscriptions and prescriptions of village doctrines and canons afforded us individual freedom to operate in Pacific Island spaces - in island countries as well as diasporic communities - beyond the rules applied to Natives. There was privilege connoted in that very freedom of mobility and choice; do I choose to go along with village dogma, or, will I shift outside this system of belief to function as myself, a person of difference?

We have written on privilege elsewhere. (Brown Pulu and Pamatatau, 2015a, 2015b). Interrogating our own Native and European heritages of mixed-race, we prodded at how the halfcast identity signpost in Tonga permits us a type of social freedom to cross conservative cultural borders that people marked as full-blooded Natives are not meant to pass through.

Often we are reminded by Tongans and other Pacific Islanders in the field that we have privilege as outsiders who are released from cultural constraint and social obligation. But there is also acknowledgement that we are insiders of a specific kind too.

We signify a half-cast breed performing European-ness over and above Native-ness. This entails coming across in public, and having the Natives take us as, Palangi in speech, tastes, manners, and characteristics.

Scanning Edwina and Maurits' observations of Kolonga day, we have reflections to add. To begin with, they noticed performance aspects of displaying traditional wealth that Richard and I did not concentrate on. The visual appeal of 
koloa put on show, as in high-quality mats put under the table where Nuku, the noble of Kolonga and his family sat, and ate, impressed them considerably.

Then there was Maurits' view that "while the room was chaotic that was caused by the room size because the people were operating in their spaces beautifully." His opinion was noteworthy.

Could it be argued the main hitch about Kolonga day hinged on the fact the room was small, cramped, and posed a health, safety, and fire risk for the number of people in attendance? Given this may have been the case, if the organising committee had of anticipated the sizeable crowd by hiring an oversized venue, would it have resolved the inconvenience, chanciness, and anxiety of an undersized setting?

To end with, there was Edwina's cautioning to her son, Richard: "I've also been told not to be too critical of people trying to carve out a place." Such maternal advice is valuable.

Echoing the adage, mother knows best, her opinion is influential, as well as difficult to discount. Getting one's attitude in the field checked by their mother carries great weight. I say this from lived experience having lost my mother to illness earlier this year, but knowing the critic and conscience her voice conveyed, which if she were alive, would have warned me of two considerations.

First, being categorised and raised in Tonga as half-cast, not full-blooded Native, my mother was choosy and selective as to which Tongan functions she would allow her only child and grandchildren attend. Consequently, seeing I decided not to say no to the organising committee about giving a speech at Kolonga day, and being part of the event I was, to a certain extent, bound by the occasion's protocol and convention.

Therefore, I would have to temper my criticism by measuring it against the reality that I chose to be there. What did I envisage would take place at Kolonga day? Were my expectations unrealistic? 
Back at our workplace, Auckland University of Technology, Richard and I talked through our field-notes. Richard raised the concept of shame. It was true that we felt humiliated, discomfited, and self-conscious at the Kolonga day proceedings.

Wasteful layers of food piled on tables that did not get eaten at the feast; flabby women in tight clothes, wobbling their whopping bodies on chairs, while dancing and shouting to ear-splitting music; tacky, cheap decorations, such as sponge cakes on plastic stands that hovered above people's heads, glass beads, purple balloons, and stacks of plastic plates, canisters, and bottles.

Family spreads looked as if the $\$ 2$ Shop franchise had fixed up their tables. The sight conveyed a vulgar, bad-taste aesthetic. Although the noble's front-table stood apart from the villagers in that the meal was served on proper crockery, not plastic, it still appeared inelegant in the surroundings.

We acknowledge that being ashamed of the people and practices at Kolonga day reproduce our tastes - likes and dislikes - of celebratory get-togethers in which family share a meal by each contributing a dish. During childhood, neither of us went to big Cook Islands and Tongan festivities with crowds of people, and self-indulgent feasting.

Gathering family for a meal was done in our homes, and with modesty, polite manners, and good taste in food and décor. If our half-cast mothers had chosen to raise us around island parties in an uncontrolled carnival atmosphere, perhaps we would not think and behave as we do.

Shame and not being ashamed works on either side of the same coin. Richard and I experienced embarrassment at what was going on around us. Conversely, partakers in Kolonga day felt no humiliation about dancing and yahooing raucously.

As far as they were concerned, it was an occasion to figuratively let their hair down, and let the crowd go wild. Proudly they paraded bounteous quantities of food and 
Tongan koloa, traditional wealth, as in handwoven mats and ngatu, hand-beaten mulberry bark cloth.

\section{Chronicles in a coconut shell}

In a coconut shell, The suckling pig chronicles are untied for academic and non-academic audiences to review in the following six sections. Performing Tongan-ness in an Otahuhu Hall is a selection of Richard's Kolonga day photographs. Each image communicates a story about performing identity in diaspora. When adapting village culture to fit in an Auckland Council hall of Otahuhu suburb in South Auckland, what ambiguities and anxieties transpire?

Chronicle one is an exchange between Richard and Melino Maka, a migrant Tongan male of the sixty years plus generation. Tatakamotonga, Melino's village, is located in Hahake, the same rural district as Kolonga. $\mathrm{He}$ also photographed Kolonga day, displaying the pictures on his Facebook page with five-thousand friends and followers, mostly Tongans.

Chronical two is Teena's discussion with Toa Amoamo, her twenty-six year old daughter, and Semi Pulu's eldest grandchild. Toa is a New Zealand-born Pacific Islander of Tongan and Maori ethnicities. She speaks to her likes and loathes of the first Kolonga day, as well as the politics of being mixed-blood at a village party.

Chronicle three is a conversation between Richard and his friend Maurits van den Berg, whose parents migrated to New Zealand from the Netherlands. Maurits signals to Richard and Teena's "embarrassment factor," which he makes sense of as the descendant of Dutch migrants. Mostly, he gives a critical appraisal of why he thought Kolonga day was a "fantastic day."

Structural adjustment is Teena's mapping of the talk among senior members of the Pulu kinfolk. This is Teena's extended family. The segment probes at why they revisited their collective thinking around what Kolonga day should entail, and result in. 
The New Zealand Village are Teena and Richard's concluding thoughts. How is the performance of marginal identities in a country tracing its origins to colonial settler society, a product of cultural change? Lastly, is the future of the village celebration sustainable across generations?

\section{Performing Tongan-ness in an Otahuhu Hall}

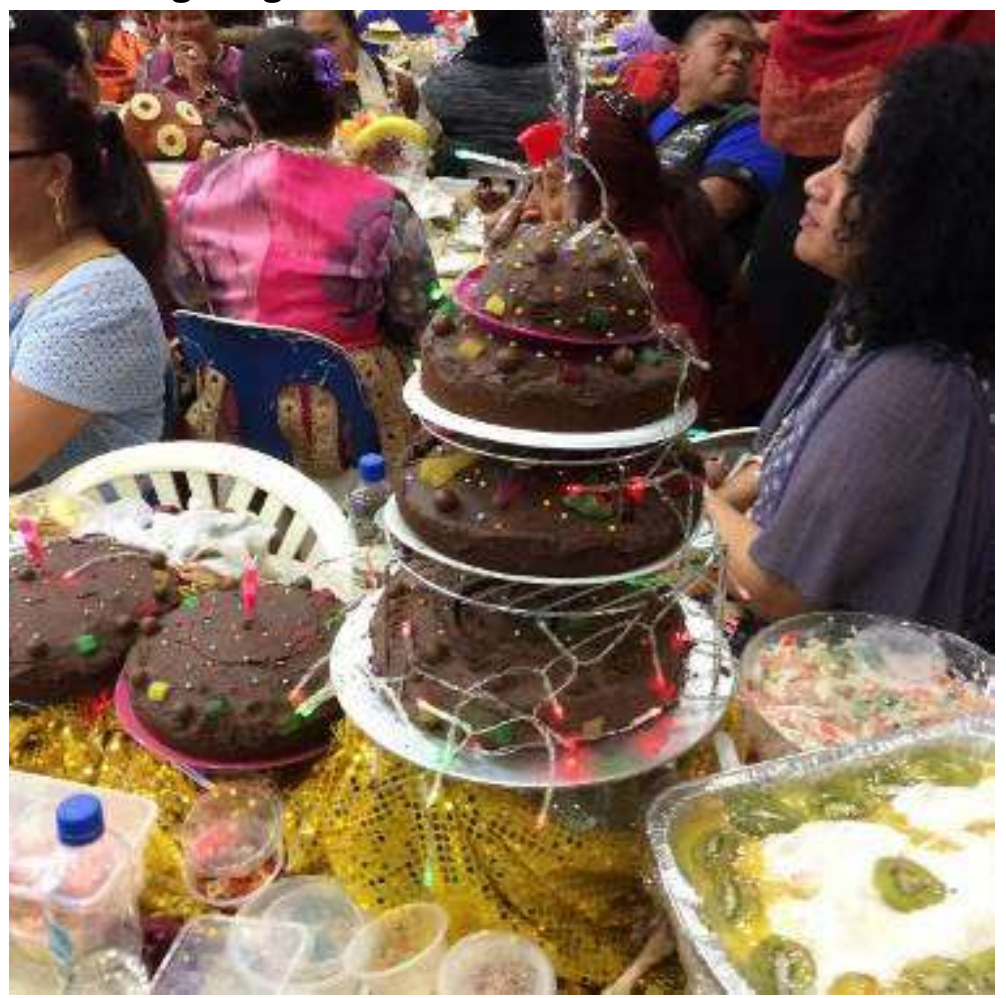

Keke (cake) and putini (pudding). Photograph Credit: Richard Pamatatau. 


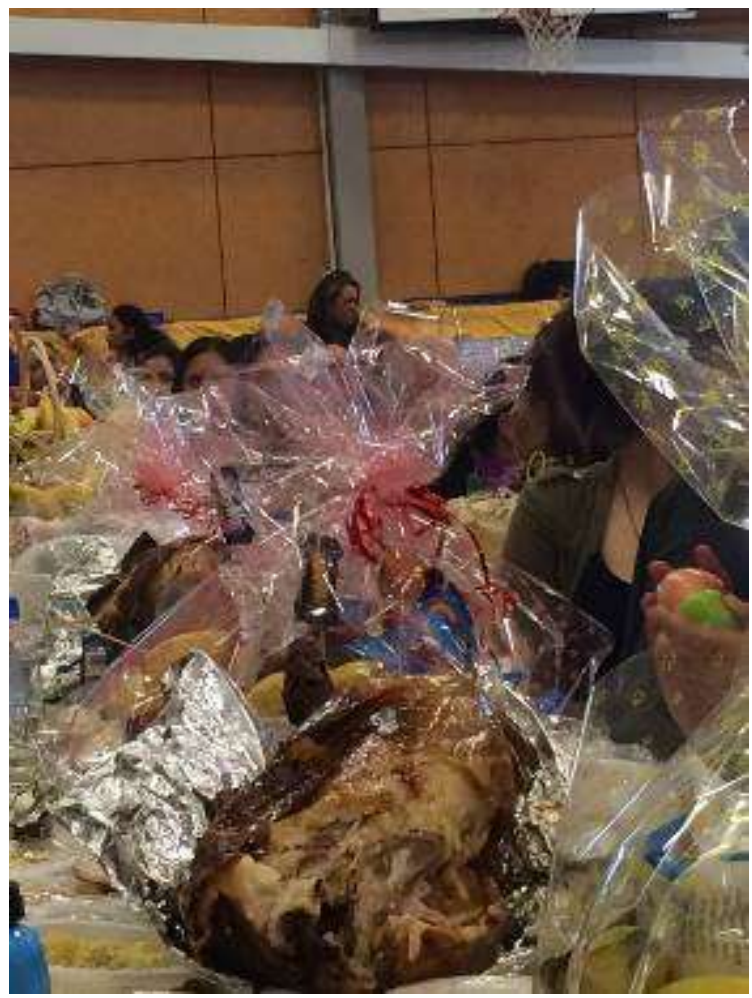

Puaka (pig) and plastic wrappers. Photograph Credit: Richard Pamatatau. 


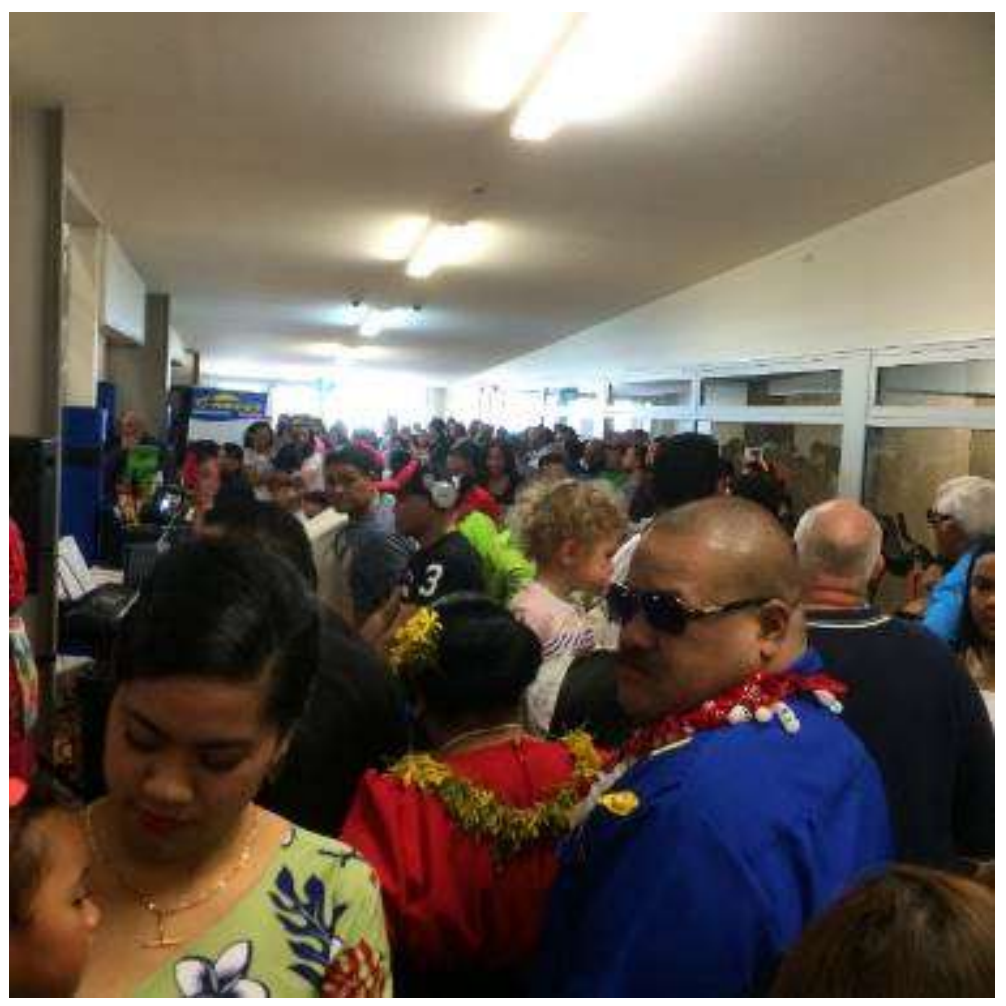

Crammed corridor leading to the hall. Photograph Credit: Richard Pamatatau. 


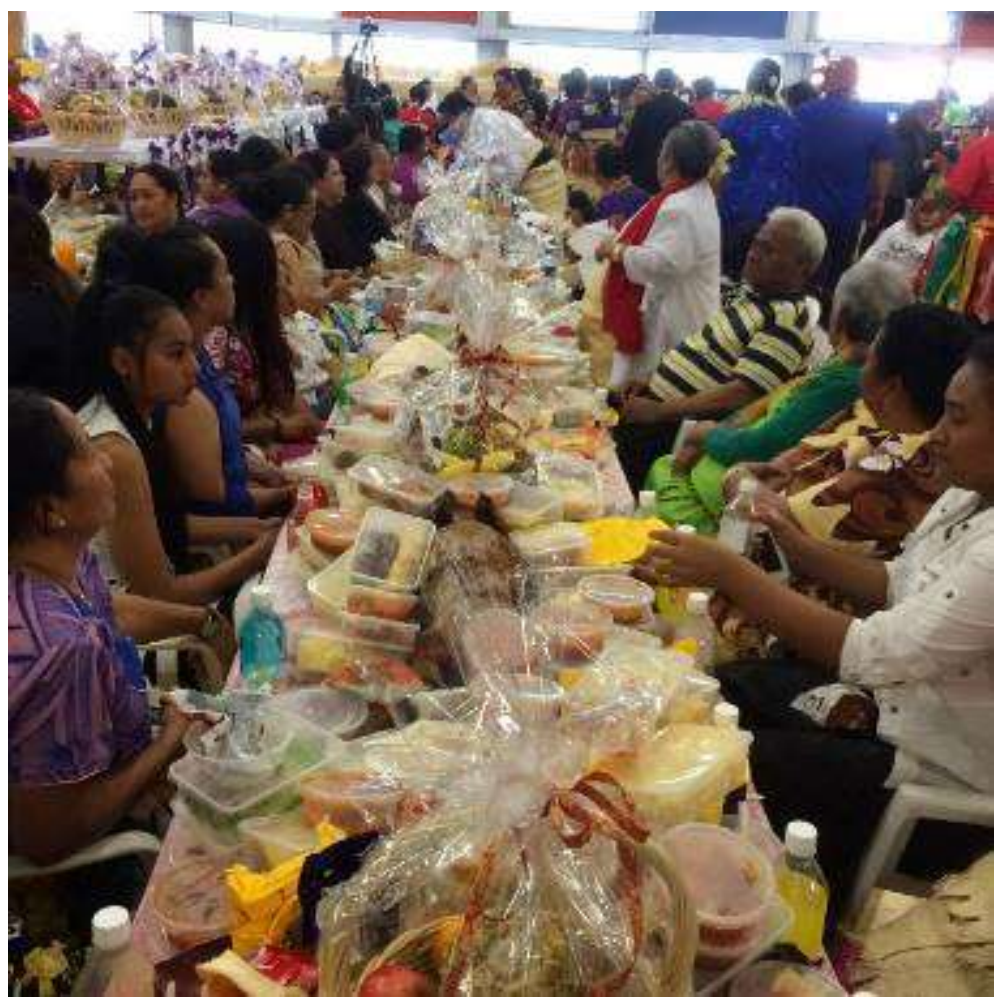

Mass production of overfull tables. Photograph Credit: Richard Pamatatau. 


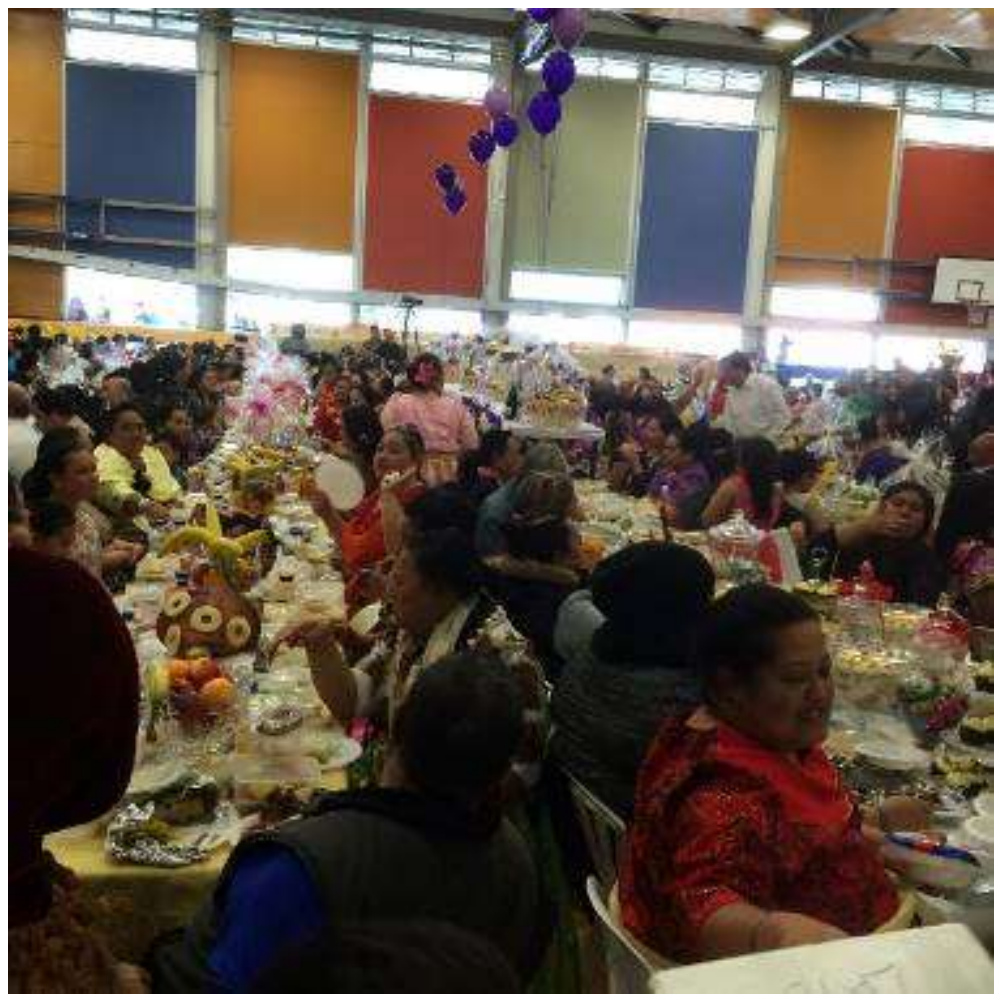

Tight fit inside. Photograph Credit: Richard Pamatatau. 


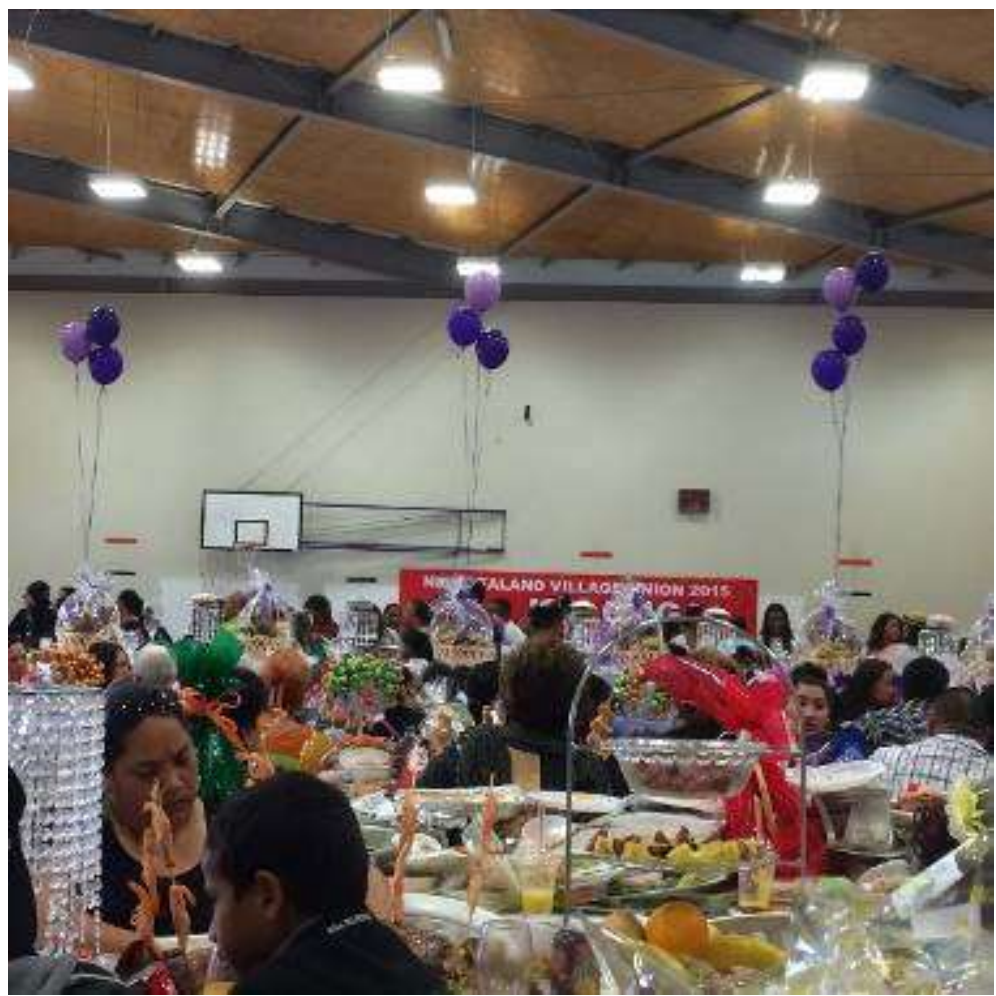

Glass beads and purple balloons. Photograph Credit: Richard Pamatatau. 


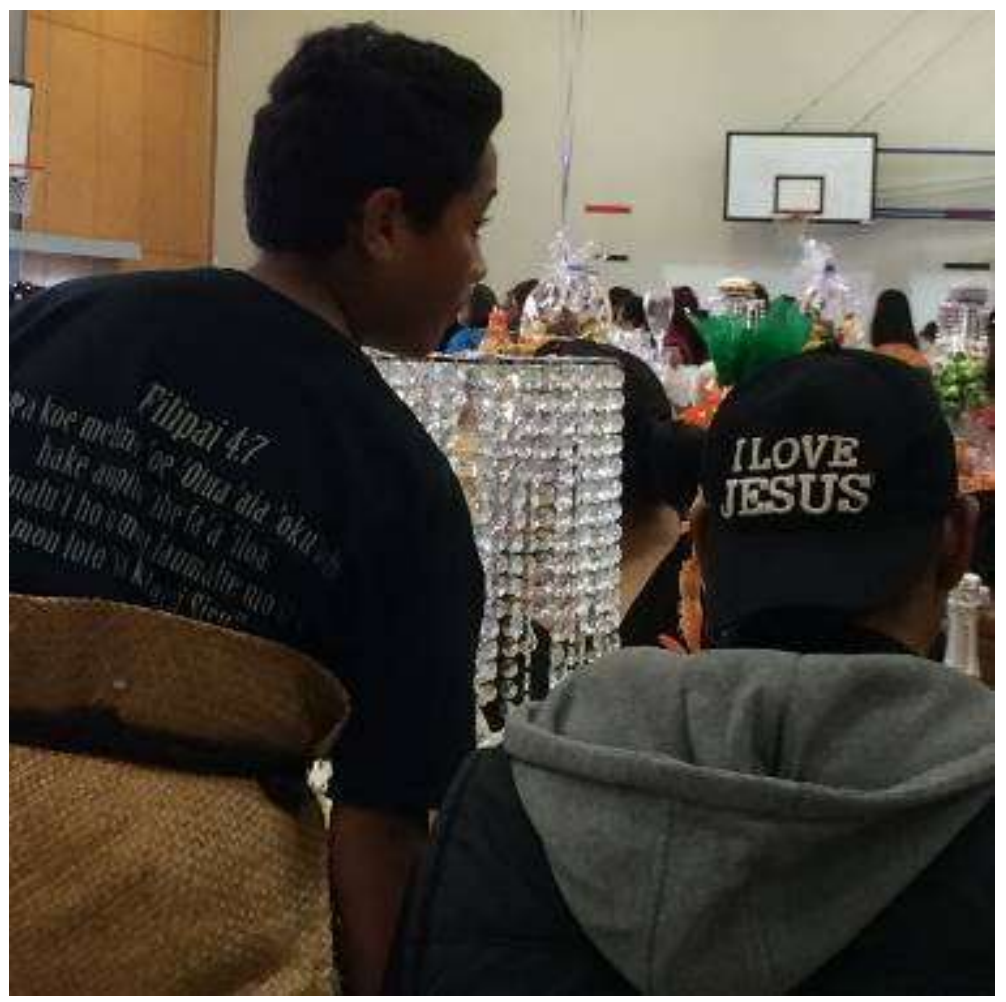

"I Love Jesus." Photograph Credit: Richard Pamatatau. 


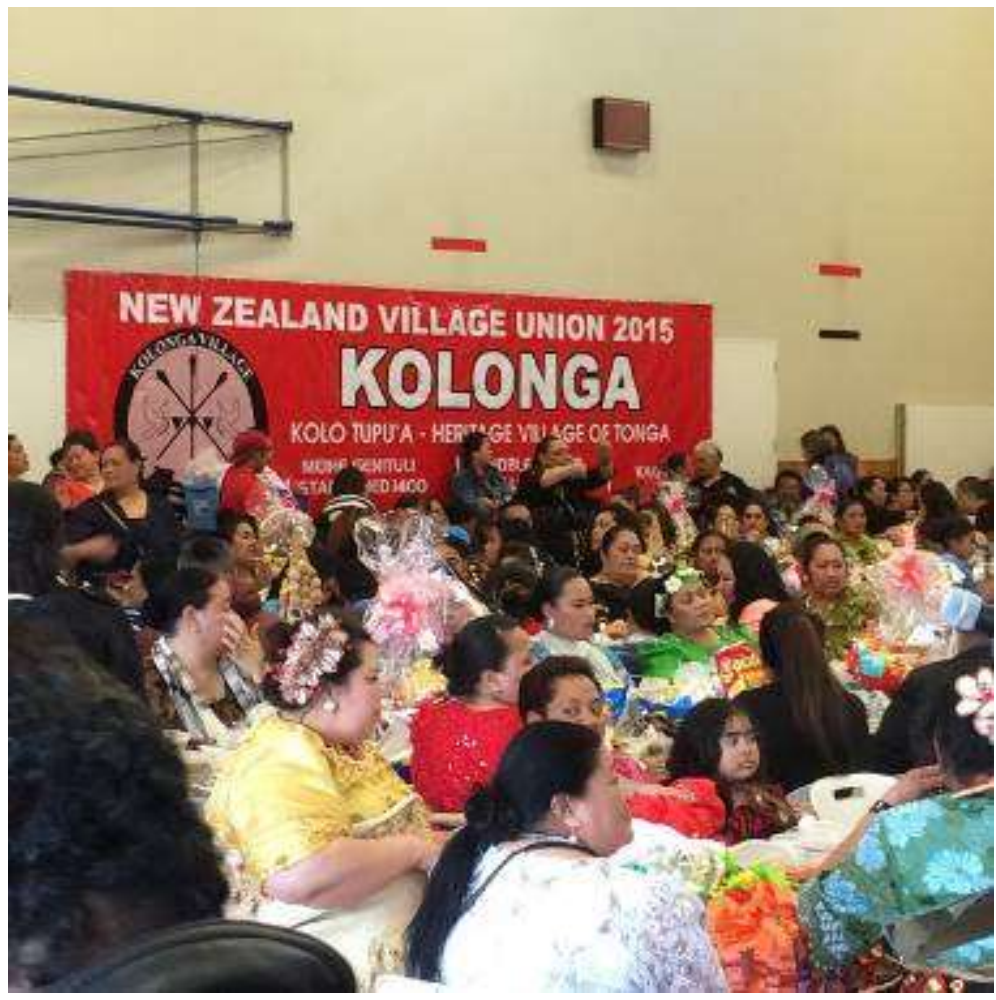

"New Zealand Village Union 2015 KOLONGA." Photograph Credit: Richard Pamatatau. 


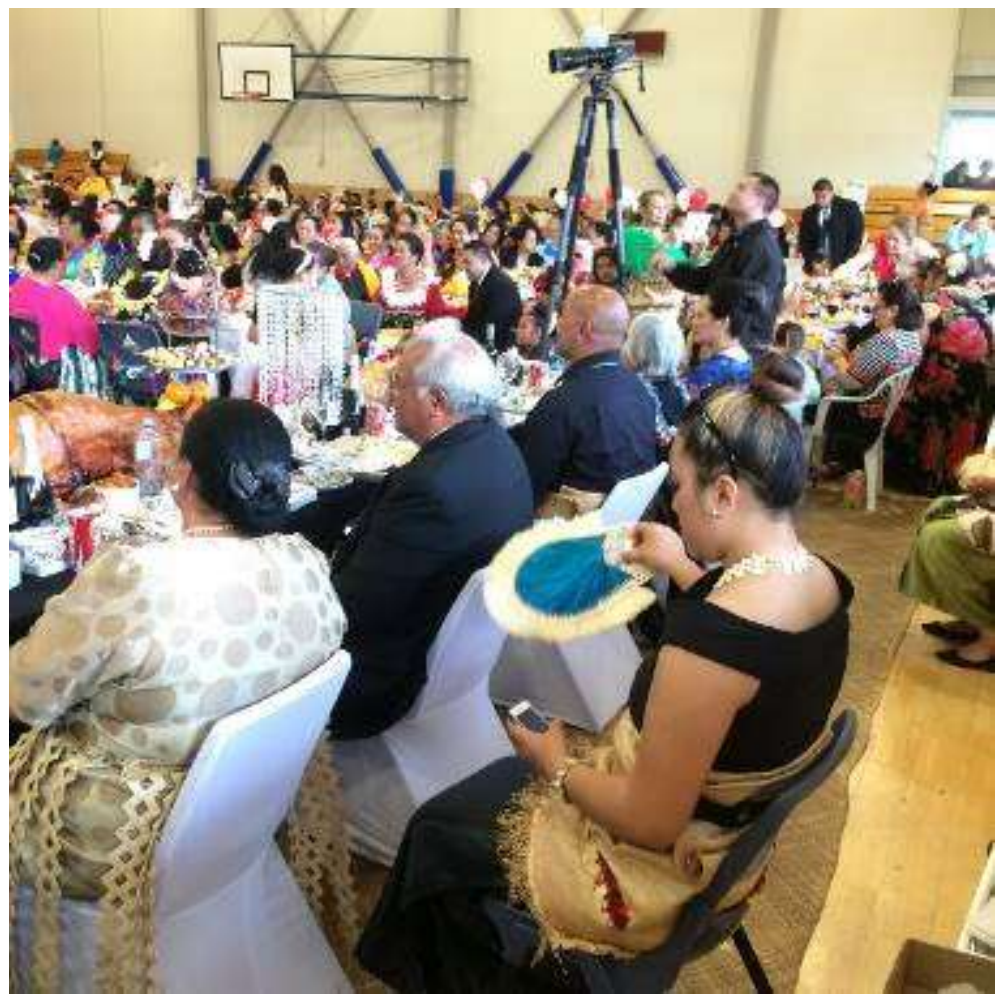

Top table for Lord Nuku and family. Photograph Credit: Richard Pamatatau. 


\section{Chronicle one by Melino and Richard}

Melino Maka migrated to Manawatu in the 1970s to live with his uncle, and work in the meat industry. He is now sixty years old, and lives in Auckland. The Pacific Islander experience of being introduced to New Zealand life in a small town, rather than Auckland, is significant. Migrants who know small town New Zealand are different to their Auckland counterparts. Melino exemplifies this through his outspoken and independentminded character.

Richard: What did you think of the Kolonga day event?

Melino: This [is] typical of a Tongan community event - the key thing is to celebrate - but what is the purpose, what would be the purpose of such a day?

It's a huge event and a feast, and at Kolonga day, the turnout was underestimated, and others just turned up because they heard there was a feast on. But really, the money that was spent could have been used for a project in Kolonga, or something more productive, rather than a lot of eating. What is there to show for it after three-days of celebration?

I ask you, what is there to show for it?

Richard: What do you mean?

Melino: It went beyond being a Kolonga day. It should have been a conversation with the people, and more direction [given by the organising committee, and family leaders] of how to use New Zealand resources to do things back in Tonga for the village, and district, and that can make up for the lack of Tongan government direction when it comes to [building and sustaining] infrastructure [in the rural districts].

Kolonga is the biggest village in Tonga in terms of the space - the length of the island it occupies - and this is where the work needs to be done, and also to think about what it means to be a New Zealand born Tongan.

Richard: Can you tell me a bit more about what this means? 
Melino: Deep down, we all know where we come from as Tongans, and this event could have been a chance to tell New Zealand born Tongans - people from Kolonga [specifically] - more about culture and things [historically significant to the village].

If you ask New Zealand born Tongan[s] what they learned from this, they would struggle to tell you anything if the emphasis is on culture, rather than needs. It could have been a chance for New Zealand born Kolonga people to reconnect, or connect, with their culture and their roots. There is the possibility with an event like this, for strong cultural knowledge to be imparted, and this is where they can start to look for it.

[To] focus this generation on this, and draw from a base of cultural wealth, would have been an idea. But, this is where we see a lack of leadership, and no vision for ten, twenty years, out[right]. Instead, it is a focus on today, and the big feast.

They decided to have it anyway, and now [it] means people are thinking about how it can be made to be more forward looking.

Richard: Any other issues?

Melino: The size of the crowd shows there is a need for some kind of event for Tongan people in a big group. So maybe, what needs to happen is more thinking, and a different kind of venue, because you could see they were breaking all of the health and safety rules by the numbers of people who were in the hall. And, also because at the top table they were serving alcohol, and that should not be happening at all at an event like this, but maybe that was because it was for the top table [where the noble and his family sat with their guests].

Richard: My non-Tongan family and friend loved the whole day, and said people were wonderful to them. Why do you think that is? They thought the tapa, ngatu and fine mats were amazing. 
Melino: Tongans are always very hospitable to nonTongans, and your mother and friend were obviously not Tongan - so of course they were looked after - let through [the crowd] to get a good view of the ta'olunga [traditional female dance], and the koloa [traditional wealth, as in ngatu and mats].

And it is natural for people to offer them seats, and drinks, and something to eat. We always want our guests to be treated well, and it is excellent that that take that away with them. But, remember they are not Tongan, so might not have recognised everything that was going on, and that is fine too.

I keep coming back to what is the outcome - the outcome for your family and friend was a wonderful day, and that's one important part of the day - sharing our Tongan culture. But then I come back to the community, and what it will say in six-months or twelve-month's time. What did it get out of it?

And I come back to the fact the hall was overfilled, and there were people who were connected to Kolonga, and people who were not, and again, that they broke the council rules, though maybe they did not have much of a chance because so many people wanted to come.

I think we need to think about how we nurture culture in a two-way process, and people must respect the culture, and also being in New Zealand, so that makes it difficult because we are remembering the village, but living in New Zealand. I think people get excited by the idea of the village day, and it's time to think about [going] beyond a feast with all that food, which will have cost some families who can't afford it, a lot of money.

Chronicle two by Toa and Teena

Toa Amoamo is the adult daughter of the co-author, Teena Brown. She is the eldest grandchild of Semi Pulu, Teena's father, whose Tongan village Kolonga and its descendants living overseas is the essay centrepiece. Toa identifies as New Zealand Maori on her father's side, and New Zealand born 
Tongan on her mother's side, thus, holding to strong views on being mixed-identity in a village setting.

Teena: Kolonga day, what did you think of it?

I thought it was a mess, chaos. Well really, I thought it was interesting, amusing, and could go both ways. If you were to look at it in a more positive way, there was a knowledge gap between the older migrant generation, and the younger generation born here who speak Tongan, but don't go back to the village.

The contrast between the old and new generation; the older ones were there to celebrate, but the younger ones were disillusioned as to what the purpose of the event was. There was a lack of activities, and things for the young ones to do, to help them get engaged.

Watching kids at the tables, they seemed to be there to be respectful and to represent their families. But there's a disconnection there, it's obvious. There were kids waiting outside in the hallway, outside the building looking in the windows, and it's difficult for New Zealand born Tongans to make a connection to the village, like where do I fit in with Kolonga identity, if they've never been to the village.

Teena: What is your tie to Kolonga? Do you have much to do with the village and the people?

Granddad's family obviously, the Mailau and the Pulu families of Kolonga. We had more to do with Grandma Siu's Mailau family, that's Granddad's Mum. I came to know them better as an adult when I moved to Auckland for education and work because I stayed with Grandma Tiueti in Ponsonby, Grandma Siu's younger sister.

No, I don't have much to do with the village and the people because I was born in New Zealand, and my Dad's Maori. Then there's Grandma's influence over us as well, my Mum's Mum, there's her half-cast influence. I don't like the term half-cast. I prefer hafekasi because that's more appropriate to me. 
Grandma wasn't an ordinary Tongan. She didn't mix with everyday Tongans; Tongans that go to church every Sunday, and speak Tongan in their homes, and do all of that Tongan obligation. She was a very classy woman. She didn't mix in Tongan circles all of the time. She didn't mix in Tongan circles at all really, and neither did we because of her.

Teena: Describe being Maori and Tongan in a village setting?

It's very complex because Maori and Tongan cultures are very different, even if there are similarities. At the end of the day, their priorities are different. Most Maori families nowadays tend to stick to the nuclear family, whereas a lot of the families from Kolonga because it's a remote, isolated village, they have bigger extended families. It would be fair to say they're a lot more Christian than most Maori families I know. Their obligations to family and service to church seems to be more of a priority.

I think a lot of people, particularly from Granddad's family, are real village people in the middle of nowhere out in the bush, and they're very clan-like. I think they just see you as a granddaughter or daughter of so-and-so. For example, if you come from a well-respected family, and they have a lot of status and ties to the nobility in the village, they see you as a niece, a daughter, a granddaughter.

When I went back to Kolonga they saw me as Semi Pulu's granddaughter, or Dr Teena Pulu's daughter. They don't see me as a school teacher, or whatever you do for your occupation. They're the only people in Tonga who call my Mum, Dr Teena Pulu. In town, my Mum is Teena Brown; she's known as Teena Brown not Teena Pulu because Grandma named her after her big sister, Tina Brown.

But Kolonga people drop the Brown completely, and call her Dr Teena Pulu to try and claim her as Kolonga, even though she's always with her mother's family at Haveluloto in town. Mum hates Tongans not saying Brown because she 
grew up in the Brown family of Haveluloto, and that's her name; that's who she is in Tonga.

Teena: What did your cousins get out of Kolonga day? Will they keep going to this event?

I'm not too sure. Based on what I've heard and been told, a lot of them felt that there could be more room for improvement in terms of establishing a programme suited to their needs and interests as descendants of Kolonga.

A programme would have to be a lot more structured in terms of time management, setting activities for young ones; for example that families play sport against each other. Or, it maybe that some of the younger ones are in leadership roles for their families, and are given the opportunity to speak about what they're doing to strengthen ties with the village, their education and work achievements, so the village gets to know them.

That's why I said at the beginning it was a mess. I meant it seemed really chaotic, and disorganised, and only about having a big feast for Nuku because he'd come over from Tonga with his family. There's got to be more to Kolonga day than that to get the young ones connected and engaged.

Chronicle three by Maurits and Richard

Maurits van den Berg's parents are Dutch migrants, which underpins the dialogue because his impressions of Kolonga day are empathetic. He related his ancestral roots in the Netherlands to the exhibition of Tongan culture in Auckland, and made no harsh judgement on excess food, tacky table decorations, and an overcrowded hall. Maurits' critical appraisal broadened a general understanding of why Kolonga day mattered to the people who staged it.

Maurits: I loved Kolonga day as I'd never been to anything like that before. While my parents, who are Dutch migrants, kept us away from anything to do with the Dutch community in terms of those kinds of events, and possible it was for the right reasons, this event was fantastic to me. 
It is not always that easy to go to events in New Zealand where you can feel completely at ease. Many places always have a tone that you can't identify, but, if you are not of Kiwi settler stock, then you probably pick up on it more than your average New Zealander.

Anyway, I loved it. It was crowded, and it was hectic, and you say it was chaotic, but what did you expect it to be? It was a community of people coming together, and you have to expect that, and mercifully, there was colour, not a whole lot of people in All Black supporter shirts, and it wasn't about the rugby. But, I don't know what it was about, except you tell me it was the people from Kolonga, which is a village in Tonga, where I have never been. So, other than that, it was people getting together to have fun, and eat, and show off, and be a community, probably in a place [like Auckland] where they don't have visibility as people from Kolonga or Tonga, as opposed to being Pacific Islanders or Polynesians, which is how a lot of people would look at them.

And it felt very different to [the Auckland] Pasifika [Festival], which I've been to a few times. Here, you knew they were a group of people with an identity that they knew all about, or at least that is how it appeared to me. And, the man I was talking to who works with Teena's father, Roger, he loved it.

The food was fantastic and you didn't have to feel guilty about having a big plateful and it was delicious. The lamb was stunning, there was plenty of it. I loved the salad and the generosity of the servings. And, I loved that people made space for me and your mother to sit down.

I know you had some embarrassment factor going on and possibly I would have had the same if I had invited you and your family to a Dutch community event. But, I wonder if that has to do with some inbuilt shame or anger at how you think Pacific people should be seen. I know I might have the same view about Dutch people because people always ask us about clogs. 
Richard: Didn't you think the food was over the top and there were too many people in there?

Maurits: What do you mean by over the top? It was food for a celebration, and it was in packages that were easy to take home, so there was another set of actions taking place. Yes, the tables were laden, but people could take things home.

Richard: What about the décor - the plastic beads, balloons, and cakes on stands, etcetera?

Maurits: Have you ever been to [a] carnival in the Netherlands? This is what people do when they celebrate, and it is their choice how they do that. On Kingsday in the Netherlands, everyone is wearing orange with balloons, and hats, and suits. I'm not sure I would do it, but it is the same thing, and anyway, what is wrong with people going over the top and showing off their mats for their waists, or their long pieces of tapa cloth, which were amazing. I had never seen anything like that before, and I wonder why we don't see more of it in everyday life. We see enough of everything else.

And actually, here is something to think about too. We see [the] display [of wealth] everytime we go on the motorway. People in their flash cars are doing exactly the same thing as people [who] bring out their best mat, or lots of food, and tapa, or balloons. People on the motorway are displaying themselves, and their ability, or power, through a car, and we think nothing of it and probably would not mind to drive such a car ourselves. I think it is fine for [a] community to show off to itself. It's hard enough [with] people showing off [in Auckland] anyway, so from that point, Kolonga day is fantastic.

And, you think about how other groups show off. They go to the Philharmonia, or art openings, etcetera.

Richard: Would you go again?

Maurits: If I was invited, yes. But, I wouldn't go without an invitation because I prefer to do outdoorsy things. But yes, I probably would because it was interesting, and people made me feel welcome. But, I suppose what I might 
like to see more of is performances, but that is my need, and not that of the people whose day it is.

Richard: Do you think the day should have more of a purpose to it?

Maurits: Are you saying they need to fundraise for the village back home, or have some sort of strategic plan? Well, I think they need a bigger hall because people clearly loved to get together as Tongans, and that is wonderful. Maybe something in an outdoor park, but as for developing the village back home, that's up to Kolonga people to decide, and it's not my place to tell people what to do. And actually, it seems to me there is very little difference between this event, and things the Dutch community organise, where one group wants one thing, and another group wants another thing, and somehow you meet in the middle.

And, what do you mean by purpose? Seemed to me the purpose was to get people together, and that sure happened. And again, I come back to when does that group ever get a chance to say - this is who we are - and not be defined by other people, which happens all the time.

And actually, people were really nice when we made our way to the front. They offered us seats, and drinks, and food, but really we just wanted to see the performances, which is probably a Western way of looking at things.

I think it was a fantastic day, and maybe you should relax and enjoy it, rather than worry about what other people who you invited think of it.

Structural adjustment by Teena

On Saturday October 31st my father Semi Pulu put on a meal at his home in Manurewa for senior members of the Pulu clan. Wrapping up their involvement in Kolonga day for 2015, the menu was barbeque and salad. A week after the village celebration, this was an ideal time for extended family to reflect on their impressions of what the day entailed, and the outcomes, beneficial or otherwise. 
There were side events to the actual village day held on New Zealand Labour Day, Monday October 26th, 2015, from one o'clock in the afternoon to after eight in the evening. Namely, two balls were staged on Saturday October 24th and Saturday October 31 st at the Greyhound Conference and Function Centre, located in the Manukau Sports Bowl on Te Irirangi Drive. A Tongan businessman who had married a Kolonga woman and ran a private company in Auckland called Catering Professionals Limited, hosted the balls.

In addition, there was a meal for Nuku and his family hosted by the organising committee on Tuesday October 27th, the evening before he flew back to Tonga on Wednesday 28th. The dinner was invitation only in that it was exclusively family leaders selected by the committee who were allowed to attend.

This ethnographic recollection focuses on the Kolonga day feast because it was the main function the Pulu clan attended, and worked towards providing food for. At Semi's October 31 st barbeque, the small gathering of seven people structurally adjusted their collective thinking. Although they appreciated the coming together of village families residing in Auckland, they saw the existing form of Kolonga day excessive, expensive, and overcrowded feasting - had its downside.

As one of the Pulu kinfolk, I was relieved to hear their stance. I admit this as personal judgement: watching people at Kolonga day exhibit gluttony and piggishness around an abundance of food, uneased me. I felt embarrassed hearing accounts of packing up tables at the feast's conclusion. Loads of leftover food literally vanished into thin air. Individuals had plastic bags and styrofoam boxes to cram food in to take home.

On the tables food was put in plastic containers with sealable lids to make it easier to remove at the feast's conclusion. There was no talk of distributing the excess feast among extended family. Instead, a smash and grab mentality took hold. People went out to get their stash for themselves. 
"It is not culture," remarked my father Semi Pulu. "People say this is culture, but it's not. We don't behave like that in Kolonga. So why do that here [in New Zealand]?"

Semi was the eldest male member of the Pulu clan living in Auckland, and their New Zealand-based leader. He held to the view that village behaviour had, in some ways, changed for the worse in overseas communities. His memory of sixty-eight years had no recollection of people in Kolonga village greedily snatching food after a feast.

Whether the village in diaspora had moved away in conduct, convention, and custom to the village in the Tongan state was secondary to the essential point Semi made. He was recalling an ethical code of behaviour: not being decadent with food was one fundamental principle of village life determining a villager's propriety and place in this small settlement and society.

A second matter in need of improvement was brought up: the place of history in village day speeches, information sharing, and the programme given to the people. Semi thought Kolonga day turned into a celebration without history. Failing to retell village history, especially life stories of various chiefs and community leaders who made Kolonga well-known in Tonga, meant the Auckland tribute ended up as empty oratories given by unknowledgeable people, and excessive feasting.

Instantly the assembly of senior clan members agreed with Semi, recognising their principal ancestor, the noble Nuku Pulu, had been disremembered in Kolonga day speeches. This argument linked to a sharp prod around front-table seating: why were the noble's people - lines of the Nuku title - not seated at the head table with the title and estate holder? The maternal family of the current Nuku were placed in front before the paternal clan whom the title descended from. Why had an Auckland location changed protocol?

For senior members of the Pulu kinfolk, the conversation peaked around an item of interest raised by Muna. A seventy- 
two year old Tongan woman, she was the last surviving grandchild of Nuku Pulu, the former noble of Kolonga and principal ancestor of the Pulu clan. Perceptibly the extended family had taken Nuku Pulu's name as their surname.

Muna had listened to a bulletin reporting on Kolonga day. It was broadcasted on the Tongan language show at Radio 531pi, an Auckland station for Pacific Islander communities. Stated as fact was that Semi Pulu, an Auckland council senior building inspector, exited Kolonga day early in case the feast was closed down by the council for being a health, safety, and fire risk.

Immediately Semi responded that Radio 531pi had not approached him to comment on the accusation before airing the report. "What do you think about that?" he asked Muna. Semi was speaking about the claim he deserted Kolonga day because his role at the council was compromised by the overcrowded building.

"I thought it was good you protect yourself," replied Muna. Seated around the barbeque table on Semi's deck, there was synchronised nodding in agreement. He had their vote of support to defend and uphold his employee responsibility to Auckland council foremost. After all, they reasoned, that is the main reason for migrating to New Zealand, for work and education.

While mapping the discussion it became clear this small cluster of senior members shared enduring kinship and loyalty bonds to an origin village, and common ancestors. Three generations constituted this extended family. But the older cohort of migrants over sixty-five years of age demonstrated the deepest attachment to Kolonga as their place of belonging, to their ancestors and the villagers as their people, and to Tonga as their country.

The logic reinforcing how they had reorganised their thinking made sense in this way: to them, Kolonga day was not about individuals and groups claiming relationship ties to the presiding Nuku. He was the seventeenth noble to hold the 
title and estate, and as far as they were concerned, he was not the first Nuku, and would not be the last.

They wanted to see Kolonga day run by a programme structure grounding the proceedings in village history; one where the fullness and richness of numerous nobles, and community leaders and figures, were remembered in speeches, and passed on in storytelling to the overseas communities.

Their sentiments spoke cultural truth to me when I thought of the speech I gave at the Kolonga day feast. (Brown Pulu, 2015b). Deliberately I kept to direct memory by recounting ancestors I knew.

I referred to my late grandparents Sioeli Pulu and Siu Ki Halakakala Mailau. As well, I mentioned my grandfather's older brother, Soakai Pulu, who was also deceased. He was Tonga's undefeated boxing champion for the South Pacific heavy-weight title.

I dared not deviate and spin second-hand memories I had heard of Nuku Pulu, the clan's noble ancestor. I did not know him. He died before I was born. That would be a story for senior members who knew him personally to retell.

The get-together concluded with Sione Pulu, a nephew who cooked the barbeque, thanking everyone and praying. Before dispersing, Semi announced the Pulu clan would have monthly meetings where the venue rotated around people's homes. To stay connected and strengthen extended family ties, two picnics a year would be held at Totara Park in Manurewa during the Easter and Christmas breaks.

One factor resulting from Kolonga day which impacted on the Pulu kinfolk in Auckland was self-realisation that maintaining village ties are important. The older migrant generation took responsibility for seeing to it that clan relations were reinforced foremost. Vitally it was the family of stories about the village, and principal ancestors who made it famous, which needed to be told to, and remembered and retold by, generations born overseas.

The New Zealand Village 
At Kolonga day, two sets of tensions triggering social change were going off. They rubbed up against one another causing friction, although it was only the first set that people were aware of, rather than the second.

For the most part, there were the pulls and pressures between generations: Kolonga migrants on one side, and New Zealand born Tongans affiliated to Kolonga village on the other. These two identity groups, migrants and New Zealand born, represented the internal strains and stresses that people sensed, saw, and in varying degrees, felt outright.

The second was veiled, and far more difficult to precisely pinpoint. However, it symbolised an experience that descendants of migrant cultures replanted in colonial settler societies, like New Zealand, were familiar with. Maurits mentioned his hunch on this to Richard.

It is not always that easy to go to events in New Zealand where you can feel completely at ease. Many places always have a tone that you can't identify, but, if you are not of Kiwi settler stock, then you probably pick up on it more than your average New Zealander.

Maurits van den Berg

Maurits' inkling hit the nail on the head: "a tone that you can't identify, but, if you are not Kiwi stock, then you probably pick up on it more than your average New Zealander." Who makes up the Kiwi stock? In other words who, specifically, is "your average New Zealander?" To answer, definitely not Dutch and Tongan migrants, and their New Zealand born descendants.

How many generations of Dutch and Tongan descendants have to be born in New Zealand before they are considered Kiwi enough to be proper Kiwi stock? Oddly, national identity did not altogether work like that in New Zealand, a former British colony. The baseline Kiwi stock of the country's nationhood, and historical roots, was indeed British settlers. 
More than nineteenth century Scottish, Irish, and Welsh settlers relocated by the New Zealand Company and schemes like the Wakefield Settlement, undeniably the British migrants gave New Zealand its deep-seated identity of originating from old mother England. When in modern history was the umbilical cord to the motherland cut so that New Zealand and New Zealanders could become separate to Britain as an independent country and population?

An argument could be made that the post-World War II period signified the era of shaping modern New Zealand without mother England standing over the colony, telling it how to run its domestic affairs. At the root of the Britishdescended Kiwi stock controlling New Zealand as an independent country was, undoubtedly, volatile race relations with the Native population, New Zealand Maori.

Kiwi culture had to dominate over the other for New Zealand to be Western. Therefore, New Zealand Maori was forced to be subordinate to Kiwi stock in the country their ancestors settled, and named, before Europeans knew of its whereabouts on the world map. Once subdued, the Native population was secondary in every which way, shape and form, and seen as less important to Kiwi stock, otherwise known as Pakeha New Zealanders.

In all honesty, when crafting a modern New Zealand state and society, the Kiwi stock and indigenous Maori relationship continues to be a bedrock of unresolved historical tension. (Moon, 2013). Here lies the identity knot of New Zealand nationhood that Maurits gestured to.

To be a bona fide New Zealander, one must trace their ancestry to Kiwi stock of British origin, or the Native population of New Zealand Maori, to have an established, longstanding, and recognised place in national identity. New Zealand is historically, politically, and emotionally characterised as a bicultural nation of indigenous people, and white settlers. Full stop. End of story. 
What to do if you live in New Zealand's largest town where migrants are prominent, like Auckland, and your people are not the Kiwi and Native duo personifying the country? (Spoonley and Bedford, 2012). Concoct an unorthodox celebration to Waitangi Day, Auckland Anniversary Day, and Labour Day, such as Kolonga day; not that the dominant Kiwi culture notices. Only the small circle identifying as Tongan (slash) Kolonga take their unofficial celebratory day seriously.

Kolonga day can therefore be framed in two distinct, but mutually related ways. As a substitute commemoration day replacing New Zealand's official calendar of public holidays, it corresponds to the self-consciousness and awkwardness of not being Kiwi or Native. That is, the feeling of not being a real New Zealander who in fact belongs here, like Pakeha Kiwi and Maori people.

Interchangeably, Kolonga day draws attention to the diaspora's geographic and social fracture from the homeland village. (Brown Pulu, 2002). The banner displayed at the feast was worded: "New Zealand Village Union 2015 KOLONGA." Assembling the New Zealand village was the emphasis. The village in New Zealand was important to the people staging an identity performance jammed into an undersized Otahuhu Hall.

In saying that, we have arrived at our last probe: will the village celebration be sustained by generations born and raised in New Zealand? Who knows? What is more, who are Richard and I to say? Neither of us will adopt village day as a cultural identity marker to define and confine who we are in New Zealand, and how we fit into the changing ethno-scape. (Appadurai, 1996).

Here is a tradition invented by migrant Tongans in diaspora. Uncertainty prevails over the continuance of the village feast without migrants to keep it going. Teena's daughter, Toa Amoamo, envisaged how she thought cousins of her generation, adults between twenty and thirty years of age born in New Zealand, would take to Kolonga day in the future. 
That's why I said at the beginning it was a mess. I meant it seemed really chaotic, and disorganised, and only about having a big feast for Nuku because he'd come over from Tonga with his family. There's got to be more to Kolonga day than that to get the young ones connected and engaged.

Toa Amoamo

\section{The end.}

In actuality, this is not quite the curly-tail end of Teena and Richard's, The suckling pig chronicles: Kolonga day in Auckland. An afterthought follows: one short conversation snippet of Semi, Teena, and Toa still decrypting, and making out, what Kolonga day was about.

Postscript

On Friday November 6th my father, Semi Pulu, told me he received a call on his mobile phone earlier in the week. To begin with, a member of the organising committee rang him to explain the organisers had not anticipated the size of the crowd at Kolonga day. He sounded contrite.

He then asked if Semi had belongings he wanted moved to Kolonga. The committee had paid for two shipping containers so that Kolonga people in Auckland could send goods to families in the village. The first container left Auckland that very Friday, and the second departed the following week.

Semi declined to transfer his possessions. Operating on a first-come, first-served basis, the organising committee advertised on Tongan language radio in Auckland for Kolonga people to use the containers, free of charge. They would pay shipment costs, plus road transport from Queen Salote Wharf in Nuku'alofa to the village, sixty plus kilometres out of the capital in Tongatapu's eastern district.

Time was short to organise his goods. Besides, he was preparing to ship his own container of household items early in 2016. "That's enough. Leave the containers for other 
families. Something positive has come out of this," Semi reflected.

"Do you think Nuku would have urged them to help the village?" I inquired.

"I don't know, but Nuku is very good to Kolonga people at home. He tries to help them improve the village," was his response.

"There's my big-mouth telling the Auckland crowd to do something useful for the poor village. The organising committee would take notice after my Kolonga day speech was published on Tonga NZ Net," I commented.

"Yes," said Semi, "They can't ignore that."

My adult daughter Toa, a secondary school teacher of Te Reo Maori, listened to the conversation. She had unravelled how her mixed Maori and Tongan heritage got tangled and twisted at family events. At a Tongan gathering, she was expected to be Tongan, and likewise at a Maori occasion, she was required to be Maori.

No identity space was made for people belonging to more than one ethnicity and culture who did not want to choose one over the other. It confounded her. In twenty-six years she had learned to negotiate a multiple identity, and be more than a single ethnic and cultural unit in everyday life. Why was it unthinkable for Maori and Tongan relatives to accept, and give a positive response to, different parts that make up the whole?

"Here's Kolonga day on YouTube," mentioned Toa. (Gallaher, 2015a, 2015b; Maka, 2015).

"Look at that woman dancing with a pig off the table. That's embarrassing. If Grandma was alive, she wouldn't let us go to this."

Toa was right on all counts.

Note of thanks

The co-authors thank Professor Sharon Mazer and Professor Paul Moon who read parts of this journal article, at the beginning of the writing stage. Their critical insights on cultural change, and performing marginal identities in 
mainstream society, were useful for weaving together our ideas in this work. 


\section{References}

Appadurai, A. (1996). Modernity at Large: Cultural Dimensions of Globalization. Minneapolis: University of Minnesota Press.

Bhabha, H. K. (1998). Cultural Diversity and Cultural Difference. In The Post Colonial Studies Reader, edited by B. Ashcroft, B. Griffiths, and H. Tiffin. London: Routledge, Pp. 206-214.

Brown Pulu, T. (2015a). Opinion: Village day in diaspora. Te Kaharoa: The e-Journal on Indigenous Pacific Issues, 8 (1): 28-32.

Brown Pulu, T. (2015b). Kolonga Day Speech of Dr Teena Brown Pulu.Tonga NZ Net, Auckland, October 27.

Brown Pulu, T. (2002). Turangawaewae/Tu'ungava'e: Echoes of a place to stand and belong. Journal of Maori and Pacific Development, 3 (2): 14-30.

Brown Pulu, T. and Pamatatau, R. (2015a). Fieldwork journals on Tonga's 2014 election: What is funny about that? Te Kaharoa: The e-Journal on Indigenous Pacific Issues, 8 (1): 106-138.

Brown Pulu, T. and Pamatatau, R. (2015b). Who's Who in the Zoo: Tonga Election 2014. Te Kaharoa: The e-Journal on Indigenous Pacific Issues, 8 (1): 45-105.

Butler, J. (1990). Gender Trouble: Feminism and the Subversion of Identity. New York and London: Routledge.

Gallaher, S. (2015a). Kolonga Day Celebration, 26 October 2015: Part I. YouTube, Auckland, October 26.

https://www.youtube.com/watch?v=XtwbLXUgXpM

Gallaher, S. (2015b). Kolonga Day Celebration, 26 October 2015: Part II. YouTube, Auckland, October 26.

https://www.youtube.com/watch?v $=\mathrm{CjORgOXe} 2 \mathrm{Xk}$

Hobsbawm, E. and Ranger, T. (Eds.) (1983). The Invention of Tradition. Cambridge: Cambridge University Press.

Maka, M. (2015). Kolonga Day Celebration, Otahuhu, Auckland, Monday 26 October 2015. YouTube, Auckland, October 26.

https://www.youtube.com/watch?v=8eIDWesa-C4 Moon, P. (2013). Encounters: The Creation of New Zealand, A History. Auckland: Penguin Books.

Spoonley, P. and Bedford, R. (2012). Welcome to Our World? Immigration and the Reshaping of New Zealand. Auckland: Dunmore Publishing Ltd. 